\section{Information service goes}

\section{Sydney}

Money earmarked for the Australian Science and Technology Information Service (ASTIS), a science resource for the general public and the media, has been cut from the government science budget, allegedly to pay for ballooning expenses in the administration of the Australia prize. The prize is a new $\mathrm{A} \$ 250,000$ international award to be given in the biological sciences related to agriculture and the environment, and its first recipient will be announced on 9 April.

The federal government was advised by the Australian Academy of Science (AAS) as early as 1984 that the administrative costs of the Australia Prize would run to $\mathrm{A} \$ 200,000$. These costs are now admitted to be $\mathrm{A} \$ 160,000$ for the first year and $\mathrm{A} \$ 100,000$ for each subsequent year. Nevertheless, the May 1989 budget mentioned no administration costs, only the cash value of the prize, and the scientific community had become increasingly apprehensive that the large sums needed INTERNATIONAL COOPERATION

\section{France and Israel stay close \\ Jerusalem}

DEFYING a recent call by the European Pariament to boycott scientific cooperation with Israel, France last week signed a \$2-million binational agreement for joint research over the next two years. According to the terms of the agreement, each country will spend $\$ 500,000$ for joint research in supercomputer hardware and software and $\$ 500,000$ on biotechnology.

The European Parliament last month passed a resolution asking the European Commission (EC) to freeze funds earmarked for scientific cooperation with Israel as a protest against the continued closure of Palestinian universities in the occupied territories.

The Israeli Ministry of Science and Technology responded by saying that if Israeli and European scientists were presented from cooperating on research projects, the reverberations would go well beyond Israel's borders. Arye Shumer, the ministry's director-general, said that such a move could be "lethal", and advised the European Parliament to consider "who would really be hurt" by a boycott. He mentioned the extensive and close ties between scientists here and their counterparts in Europe, and added that the EC is one of the most important sources of funds for Israeli universities.

The agreement with France brought a sigh of relief in Israel. Shumer said it proved that scientific ties with the EC were unbroken.

Lisa Perlman UNIVERSITY OF CALIFORNIA

\section{San Francisco}

would be be lost from the science budget.

A spokesperson for the Department of Science said that the funding for the Australia Prize had been "allocated from the start" and that if the prize were cancelled "the money wouldn't have gone back to the science budget". But according to the opposition spokesman for science, Peter McGauran, the axing of the science information service ASTIS, which was to have been supported to the extent of $A \$ 400,000$ a year for three years, is a consequence of the unaccounted costs of the Australia Prize.

Professor Bob Crompton, the chairman of the AAS working party charged with developing the ASTIS proposal, wrote to the Canberra Times that "the impact of an information office servicing the media and therefore the public for 365 days a year would be greater than that of a prize, no matter how prestigious, that catches the public attention fleetingly once a year". The Minister for Science, Barry Jones, has been increasingly critical of ASTIS, saying that similar US and UK media resources deal with only 4,500 and 1,600 calls a year respectively, and that ASTIS, because of Australia's smaller population, would receive no more than 500 calls a year.

In a letter to the AAS president David Curtis, Jones argued that that "when science-related stories blow up, for example Voyager 2, cold fusion, gene shears and the San Francisco earthquake, a mass of readily available information is generated very quickly. . . . The experienced ones won't need [ASTIS] and the novices are unlikely to try." But Alan McGowan, who is president of the US media service SIPI (Scientists' Institute for Public Information), has written to the executive officer of ASTIS to say that Jones is mistaken: "Every independent observer of the media resource service here has commented on its success and its growing importance in explaining science to the public". In fact, ASTIS originally arose out of comments made in 1984 by Jones, who called on scientists to communicate with the public and with the press. In the past three years an ambitious feasibility study has been completed with the financial support of every Australian university, the Commonwealth Scientific and Industrial Research Organization (CSIRO), the Department of Industry, Technology and Commerce, of which the Ministry of Science is a part, and with additional corporate sponsorship of A $\$ 330,000$ over three years.

Despite the government's abandonment of the proposed service, Curtis says AAS "has not deserted the idea of ASTIS. ... The US service succeeds without relying on the government, and so can we."

Tania Ewing

\title{
Challenge to expansion from private colleges
}

PLANS to create three new University of California (UC) campuses by the year 2000 have met with a carefully crafted challenge from the state's private institutions, which argue that less-costly financial incentives might enable under-enrolled independent colleges and universities to absorb the new students expected by the UC system.

Taking pains to emphasize its wish to work with UC, the Association of Independent California Colleges and Universities (AICCU) is lobbying hard to bolster the Cal Grant programme that provides financial aid to California high-school graduates and could help them offset the cost differences between public and private institutions.

The association is well aware that the state department of finance has projected that UC must make room for 67,500 new students by the year 2005. "Everybody agrees that $\mathrm{UC}$ has to build at least one new campus to accommodate those students", said Hans Giesecke, director of marketing and research for AICCU, which represents some 90 accredited four-year institutions. "The question is do they need two or three new campuses?"

Association leaders take their case before a state assembly committee on 13 Febru- ary, on the same day that a UC board of regents will meet to recommend where in the state the first new campus should be. AICCU studies note that while some of its members are at full capacity, many are not. By changing the formula by which the $\mathrm{Cal}$ Grant awards are made, the association hopes to reverse that trend.

The grants are awarded in different amounts based on need and can be used for either public or private institutions. The current maximum award of $\$ 5,250$ a year is enough to pay UC costs but pays less than half the average AICCU member school's tuition and fees, said Giesecke. Association figures indicate that a boost to Cal Grant could enable its members to take up to 31,000 new students by 2005 . Not all would come from the same pool as the projected UC students, but the group believes many would - supporting its call for a closer look at the UC expansion.

UC officials say the private school situation is a side issue. "We've taken their projections into account in our projections", said a system spokesman. Giesecke countered, however, that the UC plans do not assume a more favourable Cal Grant situation and that the matter is still unresolved.

Robert Buderi 